\title{
Attitudes towards Islamic Banks: The Impact of Religiosity and the Moderating Role of Trust
}

\author{
Zaid Zaid \\ Senior Officer \\ State Bank of Pakistan \\ Banking Services Corporation, Pakistan \\ E-mail:.zaidmuhammadI0@gmail.com
}

\begin{abstract}
The purpose of this study is to analyze the impact of Muslim religiosity on attitudes towards Islamic Banks, considering the moderating role of public trust that exists towards these Islamic financial institutions. It identifies how trust towards Islamic banks in terms of their conformity with Shariah principles and their safe handling of deposits would affect common attitudes towards them. Data for the study was collected through questionnaires from II 3 individuals participated in the survey. The data was analyzed through correlation and regression analysis. Results showed that religiosity (belief, practice, knowledge, experience and consequence) has positive impact on attitudes towards Islamic banks. It proved that the more a person is religion conscious the more he/she is inclined towards Islamic banks. Moreover, it was confirmed that trust has positive relationship with attitudes towards Islamic banks. However, results could not identify any significant moderating role of trust on the relationship between religiosity and attitudes towards Islamic banks. Practical implications of the results and avenues for further investigation are discussed for future research.
\end{abstract}

Keywords: Attitudes, Islamic Banks, Religiosity, Trust.

\section{Introduction}

Islamic Finance and in particular Islamic banking is growing tremendously in the flourishing global financial sector. Over the years, Islamic banks have shown better ability of stabilization as compared to their peers, conventional financial institutions (Setyobudi, Wiryono, Nasution, \& Purwanegara, 2015). It is evident from the fact that Islamic financial industry since its inception has fused itself in the worldwide financial system and has become a major component of the mainstream finance (Lee \& Ullah, 2007, 2008).

According to Kolar \& Zabkar (2014) attitudes of the people play a pivotal role in shaping their behaviors and decision making towards a particular object. Islamic banks are commercial financial institutions and just like other financial services providers, they need positive buying public attitudes for their profitability and survival (Lee \& Ullah, 20II). The abnormal growth in Islamic banking industry in the past years is no doubt based on the peculiar attitudes of the people towards Islamic finance (Faisal, Akhtar, \& Rehman, 2014). In terms of Islamic banks, religiosity is the most prominent factor in building positive public attitudes (Newaz, Fam, \& Sharma, 2016). People are even ready to forgo something extra in monetary terms in order to get financial services that adhere to Islamic societal objectives and are in compliance with Shari'ah principles (Gerrard \& Cunningham, 1997). However, people would of course consider the element of trust and reliability towards a particular institution before they can think of having any sort of commercial or philanthropic relationship. Trust is the cornerstone of customer-organization relationship. It is the most valuable asset for both businesses seeking and non for profit organizations. A compromise on trust is the most immediate hazard to an organization that may even cease its existence (Jiang, Jones, \& Javie, 2008; Sargeant \& Lee, 2004; Garbarino \& Lee, 2003).

Many studies have been conducted to analyze how religious factors in people may affect their attitudes towards Islamic banks (Lee \& Ullah, 20II; Faisal, Akhtar, \& Rehman, 20I4; Souiden \& Rani, 2015) and how these attitudes may ultimately lead to their purchase intentions (Newaz, Fam, \& Sharma, 2016; Souiden \& Rani, 20I5; AbouYoussef, Kortam, Abou Aish, \& El-Bassiouny, 2015). In a study conducted by Newaz, Fam \& Sharma (2016), the impact of Muslim religiosity on attitudes towards Islamic banks was examined using religiosity and its different dimensions (Belief, Practice, Knowledge, Experience and Consequence) in a second order construct. Thus, the impact of religiosity as a whole has been discussed in differnet studies. However, no attempt has been made to analyze other behavioral moderating factors that may adversely or positively affect the relationship between the multidimensional religiosity and attitudes towards Islamic banks.

This research will consider the multidimensional variable of religiosity in a second order construct to examine how it affects public attitudes towards Islamic banks. In addition, the current study intends to find how public trust towards these institutions in terms of their conformity with Shari'ah principles and their perceived safe handling of deposits would moderate 
the relationship between Muslim religiosity and attitudes towards Islamic banks. Interestingly, it is the first study to test trust as a moderator between religiosity and attitudes from Islamic banks perspective. Therefore, findings can be helpful for Islamic banks to understand how a customer's religiosity and trust towards them may influence his attitudes and how may trust affect the association between customer's level of religious absorption and his attitude towards Islamic banks.

\section{Literature Review \\ 2.I Attitudes}

Attitudes are the major internal human psychological factors that influence the way consumers behave and make their decisions (Abou Youssef, Kortam, Abou Aish, \& El-Bassiouny, 2015). Attitude is defined as the favorable or unfavorable assessment of an object or entity based on a specific psychological tendency (Eagly \& Chaiken, I993). According to a similar definition presented by Lee (2012) "Attitude denotes a learned predisposition to respond to an object in a consistently favorable or unfavorable way" (p. I0). In the sphere of attitude comes the assessment of the consumer's evaluation, opinion and purchase intention towards a particular object. (Kolar \& Zabkar, 20I4). Object is used here in a broader meaning. It includes product, service, people, brand, issue etc. The definition of attitude that is more relevant to our study is the one presented by Butt \& Aftab (2013). It says that attitude is actually the opinion and perception of people about Islamic banks. Identifying attitudes is a difficult task as they are actually mental tendencies that develop unconciously and direct our actions and decisions. Even people themselves some times may be unaware of their specific attitudes towards a particular object (Abou Youssef, Kortam, Abou Aish, \& El-Bassiouny, 2015). This behavior is more relevent to our research as when people were asked about their attitdue-religion relationship, they came with vagou, ambigous and unjustified responses which hindered measureing the relationship between reliogion and attitudes (Udell, 1965).

According to a review of 109 papers conducted on the theme of consumer's attitudes, it was found that attitude highly influences behaviors whenever some specific elements in it and in behavior coincide (Ajzen \& Fishbein, 1977). Moreover, in their study, usage of a moderator was suggested to enhance the ability of attitude in predicting behaviors. The suggestion is very much relevant to this paper, though, we are using attitude as a criterion variable. However, the moderating role of trust is introduced to examine the impact of religiosity on attitudes of the people towards Islamic banks.

\subsection{Multidimensional Religiosity and Attitudes towards Islamic Banks}

Religion is mainly measured by researchers through the variable of religiosity (Abou Youssef, Kortam, Abou Aish, \& ElBassiouny, 2015). Religiosity can be defined as the level to which an individual adopts and practices the teachings of the religion of his choice in his life (Davis, 2016). It is more than the affiliation of an individual with a particular religion. It is the extent of commitment and the level of absorption of a particular religion in the individual's life (Swinyard, Kau, \& Phua, 200I). Therefore, religiosity is a relatively broader and encompassing variable as compared to religion. Religiosity is not a unidimensional term; rather, it has several dimensions that come together to determine the comprehensive level of religious orientation in an individual as a whole. Its dimensions include belief, practice, knowledge, experience and consequence. The factor "consequence" is described in literature as the way these factors influence our daily life (O'Connell, I975; El-Menouar \& Stiftung, 20I4). The current study will examine the impact of these dimensions in a second order construct of religiosity on public attitudes towards Islamic banks. Many studies have proved the stronger influence of religiosity as compared to religion in effecting individual's behavior and decision making (Essoo \& Dibb, 2004; McDniel \& Burnett, 1990). According to Hirschman (I983), like any other variable, religiosity highly effect a person's life in terms of his wealth accumulation, studies, life style, pursuits, family members and the major decisions a person may undertake in his life.

Attitudes of a person will always reflect his degree of religiosity. The more religiosity absorbed by an individual the more it will be reflected in his attitudes. A person who is more religious will try to harmonize his attitudes and behaviors with the tenet, laws and teachings of his religion. On the other hand, the more a person is liberal with regard to his religion the more he would ignore his religious teachings in his attitudes towards different objects (Sood \& Nasu, 1995).

Lives of the Muslims are highly influenced by their religious believes (Sulaiman, 2003). Islamic Shariah is the legal law considered in performing all the worldly affairs by a Muslim. Thus, Muslims would consider the principles of Shariah before expressing or developing their positive or negative attitude towards any object (Rehman \& Shabbir, 20I0). Their attitudes towards any object would be sensitive to its legal status from Shariah perspective to not circumvent any law or teaching from the Islamic Shariah (Newaz, Fam, \& Sharma, 2016). In line with many studies in existing literature who studied the influence of religiosity on attitudes towards Islamic banks and financial products (Lee \& Ullah, 20I I; Faisal, Akhtar, \& Rehman, 20I4;Souiden \& Rani, 2015; Newaz, Fam, \& Sharma, 2016;Souiden \& Rani, 20I 5; Abou Youssef, Kortam, Abou Aish, \& ElBassiouny, 2015), the current study would investigate the below given hypothestis:

\section{Hi: Religiosity has positive impact on attitudes towards Islamic banks.}




\subsection{Trust and Attitudes towards Islamic Banks}

The variable trust caught attention in several fields of the social sciences in the last decades including psychology, sociology, history, anthropology, economics and political science due to its utmost importance in the moderen world (Lewicki \& Bunker, 1996). Though, trust seems to be a clear and concise human tendency, it is always based on some complex characteristics that are difficult to be assessed and measured (Flavian, Torres, \& Guinaliu, 2005). Several authors have described it in different ways. According to Williamson (I993), "...trust is a term with many meanings" while McKnight and Chervany (I996) says "Trust is itself a term for a clustering of perceptions”.

Nevertheless, trust is often conceptualized and measured in different ways by looking into its aspects such as credibility, confidence, reliability, honesty or benevolence (Kantsperger \& Kunz, 2010). An attempt was made in the psychology literature to sketch the conceptualizations of trust. They attempted to divide trust in to two dimensions, the cognitive approach and the emotional trust (Lewis \& Weigert, 1985). The Cognitive trust is said to be constructed on "good rational reasons why the object of trust merits trust" (Lewis \& Weigert, 1985; p. 972). Trust here is considered to be an intellectual and logic based selection. It gets screened and needs to be justified on the basis of assessing the ability, dependability and expectedness of the object to be trusted (Riegelsberger, Sasse, \& McCarthy, 2005; Johnson \& Grayson, 2005). Emotional trust is the non-rational based dimension of trust, instead of evaluating different characteristics of the object to be trusted, the trust derived instantaneously with fast behavioral attitudes based on kindness, appealing, and goodwill of the object. Thus, our behaviors, trust building and trust based attitudes are actually a combination of these two dimensions (Riegelsberger, Sasse, \& McCarthy, 2005; Corritore, Kracher, \& Wiedenbeck, 2003).

Trust has shown its irrefutable role in building customer-organization relationship in the current financial sector (Sekhon, Roy, Shergill, \& Pritchad, 2013). It develops good customer or individual attitude towards a commercial or philanthropic organization, which people avoid with an organization whose credibility is doubted (Jiang, Jones, \& Javie, 2008). From the perspective of the financial industry, there is no disagreement on the pivotal role of trust in the establishment and sustaining of profitable customer relationship (Ennew, Sekhon, \& Kharouf, 20I I). In the Islamic banking context, trusting an Islamic bank for your money is not enough as it must also comply with the Islamic financial principles. Even some in terms of product quality and other basic services may be forgone; however, compliance with Shari'ah is hugely expected (Hoq, Sultana, \& Amin, 2010). Similarly, Osman et al (2009) highlighted the same distinguishing factor of Shari ah compliance emphasizing that even non-Muslims trust Islamic banks for their righteous business. In case of a study conducted by Butt (20II) in Pakistan, it suggests that a customer will not opt for an Islamic bank if he doubts their Shari'ah compliant operations. This discussion leads us to test the below hypothesis:

\section{$\mathrm{H}_{2}$ : Trust has positive impact on attitudes towards Islamic banks.}

\subsection{Moderating Role of Trust on Religiosity and Attitudes towards Islamic Banks}

Trust moderates the relationship between religiosity and attitudes towards Islamic banks in away that this relationship will be strong in case of trust of an individual towards an Islamic bank is high. It is already argued before that higher level of religiosity positively impacts the attitudes of the people towards Islamic banks (Lee \& Ullah, 20II; Faisal, Akhtar, \& Rehman, 20I4; Souiden \& Rani, 2015; Newaz, Fam, \& Sharma, 2016). It is further argued that this relationship would be week if the the banks show non Shariah compliance in terms of their products and operations, reason being, people are even ready to forgo some in monetary term only to get financial services and products that are in harmony with the principles of Shariah (Gerrard \& Cunningham, 1997). Thus, the distrust over the products and services of the Islamic banks from an organizaitnal perspective would not only develop negative behavioral attitude but would even ceize their existance as financial institutions. The same is discussed by Jiang, Jones, and Javie (2008), Sargeant and Lee (2004) and Garbarino and Lee (2003) from general organizational perspective. The above discussion supports the below mentioned hypothesis:

\section{$\mathrm{H}_{3}$ : Trust moderates the positive relationship between religiosity and attitudes towards Islamic banks in a way that this relationship would be strengthened when trust over these banks is high.}




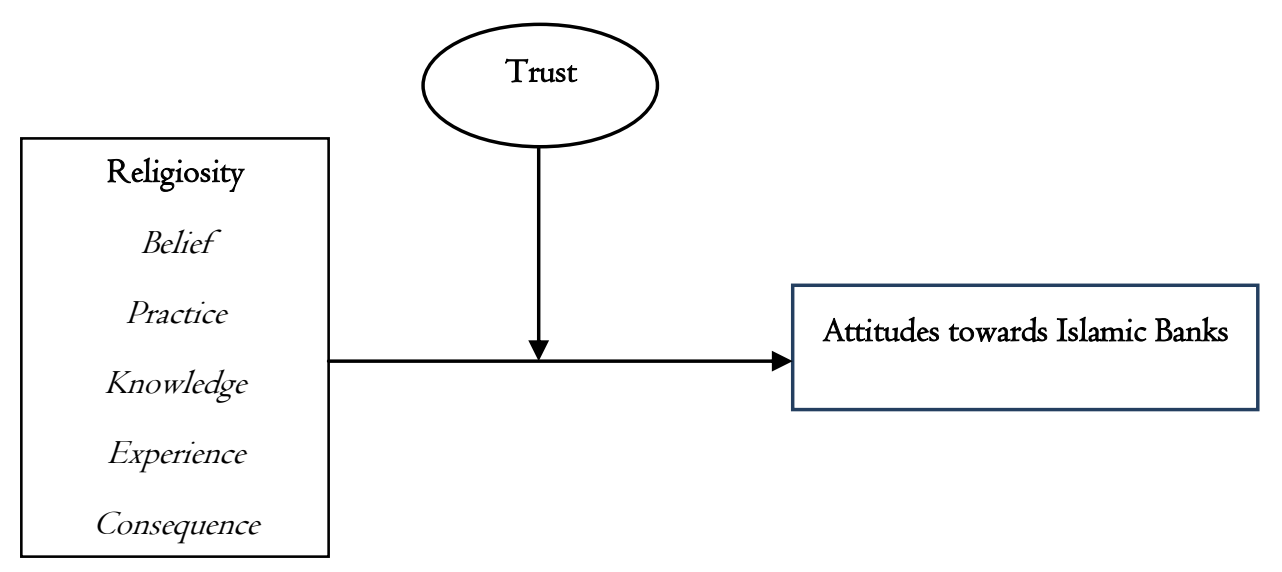

Figure I. Research Model

\section{Methodology}

\section{I Sample and Data Collection Procedure}

Data was collected from 103 individuals in Pakistan who were either existing bank customers or having an intention to get banked nearly. Individuals participated in the survey were from different education backgrounds and different qualification levels i.e. from bachelors to doctorate level. Either existing or prospective bank customers were selected to get experience based data from the respondents. Moreover, convenience sampling technique was used to collect the data through different sources including, social media, internet based research groups, mobile based social applications and through other social and professional networking websites using self-administered questionnaire technique. A cover letter was attached which explained the purpose and aims of the study to respondents. Furthermore, Confidentiality and anonymity was assured to the respondents. The participation of the respondents was voluntary.

In this study, among the $27 \%$ females and $73 \%$ male participants, majority of the respondents were below the age of 4I. Similarly, $67 \%$ and $22 \%$ of the respondents were from the age scale of I8-3I and 3I-4I years respectively while the rest were above the age of 4I. Participation by the participants having or pursuing master's degree was dominating the other qualification levels by being $67 \%$ of the total number of respondents. On the other hand the PGD holders were the least participative in this survey with a participating ratio of $1.8 \%$.

\subsection{Measures}

All the study variables were measured using a five point's Likert scale where I represented the low degree of variable and 5 represented high value of variable.

\subsection{Attitudes towards Islamic Banks}

It was measured using the three items scale adopted by Newaz, Fam \& Sharma (2016). One sample item of the scale is "Islamic finance operates in accordance with the principles of Islamic law (or Shariah)". The cronbach alpha reliability of this scale was .88 .

\subsubsection{Multidimensional Religiosity}

Religiosity is measured as a second order construct of belief, practice, knowledge, experience and consequence. The construct measures the degree of the religious attachment and the level of religious absorption in an individual. We used a I5 items scale used by Newaz, Fam \& Sharma (2016) to measure the variable of religiosity. It consisted of 5 dimensions including belief, practice, knowledge, experience and consequence. The scale of belief consists of 4 items. A single sample question is "I Believe that there is no other God but Allah and Mohammad (SWS) is his prophet". The second dimension is practice. It contains three items in its scale including "I Pray five times a day". The third variable of religiosity is the religious knowledge. Its scale consists of 3 items; "I Know the basic and necessary knowledge about my religion" is a single example of its scale. The second last aspect of religiosity is the religious experience of an individual. It is measured through a 3 items scale including the item "Religion is especially important because it answers many questions about the meaning of life". Similarly, the last dimension of religiosity is consequence. It is measured through a 2 items scale. One sample item of the scale is "I try to avoid any activity that hurts others". The cronbach alpha reliability of these scales was $.97, .75, .83, .89$ and .90 respectively. 


\subsubsection{Trust}

Trust towards Islamic banks was measured in the same way by using a 5 points likert scale of Amin, Isa, and Fontaine (2013). A single sample item of the scale is "Islamic banks are truly concerned with Islamic principles" The cronbach alpha reliability of this scale was .88 .

\subsection{Control Variables}

In order to control the variations in the dependent variable attitudes towards Islamic banks caused by the demographic factors included in the study, a one-way ANOVA was performed. According to the results obtained from one-way ANOVA (see Table $\mathrm{I})$, significant variations were found in attitudes towards Islamic banks across gender $(\mathrm{F}=4.3$ and $\mathrm{p}<.05)$, however, no significant differences in the mean values of the dependent variable were found on the basis of age and qualification.

Table I. One-way ANOVA

\begin{tabular}{ccc}
\hline & \multicolumn{2}{c}{ Attitudes towards Islamic Banks } \\
\hline Source of Variation & F Statistic & P-Value \\
\hline Gender & 4.3 & $.04 \mathrm{I}$ \\
\hline Age & .17 & .92 \\
\hline Qualification & .63 & .6 \\
\hline
\end{tabular}

\section{Results}

\section{I Descriptive and Correlation}

Means, standard deviations and correlation statistics are given in Table 2.

Table 2. Means, Standard Deviations, Correlations and Reliabilities

\begin{tabular}{|c|c|c|c|c|c|c|c|c|c|}
\hline & Mean & S.D & I & 2 & 3 & 4 & 5 & 6 & 7 \\
\hline Belief & 4.79 & .77 & $(.97)$ & & & & & & \\
\hline Practice & 4.14 & .92 & .54 & $(.75)$ & & & & & \\
\hline Knowledge & 4.29 & .87 & $.62^{2}$ & $.70^{2 x}$ & $(.83)$ & & & & \\
\hline Experience & 4.63 & .82 &  & $.62^{2 x}$ & $.70^{2}$ & $(.89)$ & & & \\
\hline Consequence & 4.42 & .87 & $.699^{2 x}$ & $.44^{\text {tax }}$ & $.58^{2 x}$ & $.72^{2}$ & $(.90)$ & & \\
\hline Attitudes & 3.57 & I.08 & $.29^{x+2 x}$ &  & $.40^{2 x y x}$ & 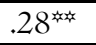 & $.23^{\text {tx }}$ & $(.88)$ & \\
\hline Trust & 3.29 & 1.05 & $.27^{x+2 x}$ & $.3 I^{2}$ & $.35^{2 x}$ & 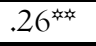 & 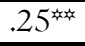 & $.7 \mathrm{I}^{2}$ & $(.88)$ \\
\hline
\end{tabular}

$\mathrm{n}=\mathrm{II} 3$; alpha reliabilities are given in parenthesis.

Table 2 indicates that there is strong positive association of the 5 dimensions of religiosity named as belief (.29, p $<.0 \mathrm{I})$, practice $(.35, \mathrm{p}<.00 \mathrm{I})$, knowledge $(.40, \mathrm{p}<.00 \mathrm{I})$, experience $(.28, \mathrm{p}<.0 \mathrm{I})$ and consequence $(.23, \mathrm{p}<.05)$ with attitudes towards Islamic banks. These results are providing primarily support to our hypothesis I. Similarly, the table also shows that trust $(.7 \mathrm{I}, \mathrm{p}<.00 \mathrm{I})$ is also maintaining a strong positive association with the dependent variable attitudes towards Islamic banks, thus, providing initial support to our hypothesis number 2.

\subsection{Regression Analysis}

The multiple regression analysis technique was used to measure the impact of religiosity and trust on attitudes towards Islamic banks. Moreover, the moderating role of trust was also examined using the same technique. Table 3 represents results obtained from the regression analysis. Results indicate that religiosity has positive impact on attitudes towards Islamic banks $(B=.2 \mathrm{I} 3$, $\mathrm{p}=.046)$, therefore, Hypothesis $\mathrm{I}$ is accepted. Similarly, results show that trust has strong positive effect on attitudes $(\mathrm{B}=.678$, $\mathrm{p}=.000$ ), thus, Hypothesis 2 is also accepted.

Table 3. Moderated Regression Analysis

\begin{tabular}{lccc}
\hline & & Attitudes towards Islamic Banks & $\Delta \mathrm{R} 2$ \\
\hline Predictors & $\mathrm{B}$ & $\mathrm{R} 2$ & \\
\hline Step I & & .037 & \\
\hline Control variables & & \\
\hline Step 2 & & \\
\hline \hline
\end{tabular}




\begin{tabular}{|c|c|c|c|}
\hline Religiosity & $.213^{\text {th }}$ & & \\
\hline Trust & $.678^{.+2 x}$ & .525 & 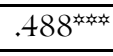 \\
\hline \multicolumn{4}{|l|}{ Step 3} \\
\hline Religiosity $\mathrm{x}$ Trust & $-0.079 \mathrm{~ns}$ & .529 & .044 \\
\hline
\end{tabular}

$\mathrm{n}=\mathrm{II} 3$,

${ }^{*}=\mathrm{p}<.05 .{ }^{*}=\mathrm{p}<.0 \mathrm{I} .{ }_{\mathrm{p}}<.00 \mathrm{I} . \mathrm{ns}=$ not significant

In order to test Hypothesis 3, the moderated regression analyses developed by Cohen, West, and Aiken (2013) was used to measure the moderation effect. In this approach, in the first step the control variable is entered, in the second step the independent variables along with the moderating variables are entered and in the third step the interaction term is entered (interaction term is the product of the mean of the independent variable and the moderating variable) which in case of significance indicates moderation. Table 3 presents the results of our moderated regression, results show that trust does not moderate the relationship between religiosity and attitudes towards Islamic banks $(B=.079, \mathrm{p}=.360)$, thus, hypothesis 3 is not accepted.

\section{Discussion}

Empirical results are found supporting two proposed hypothesis of our study. It has been found that the dimensions of religiosity are having strong independent relation with the dependent variable. Moreover, the second order construct religiosity as a whole was found to have positive impact on attitudes towards Islamic banks. Thus, higher the religiosity in an individual higher would be his inclination towards Islamic banks. It is in line with the fact that the more a person is religion conscious the higher will be the absorption of religion in his life. This higher degree of religiosity would be reflected in his actions through his attitudes towards the objects around him. The individual will strive to develop a consistent and sustainable harmony in his attitudes with the beliefs and teachings of his religion. This would not be the case if the individual has liberal thoughts regarding his religion or is having lower level of religiosity. This is true for religion oriented Muslims, as their religious teachings have great impact on their lives. They before developing their attitudes towards an object would consider Shariah commandments regarding that particular act or object. Therefore, Islamic banking being in compliance with Shariah principles will always be preferred by Muslim individuals having religious inclination. However, the degree of this inclination will always determine their level of favorable attitudes towards Islamic banks. These findings were in support of many previous studies including Lee and Ullah (20II), Faisal, Akhtar, \& Rehman (20I4), Souiden and Rani (20I5) and Newaz, Fam and Sharma (2016).

There is scarcity of literature over the subject of relationship of trust with attitudes from Islamic banks' perspective. Our study found that there is strong positive relation between trust and attitudes towards Islamic banks. This is in line with the few studies discussing some relevent behavioral aspects and their role in determining attitudes towards Islamic banks (Hoq, Sultana, \& Amin, 20I0; Osman et al, 2009; Butt, 20II). It means higher the level of trust towards Islamic banks higher would be the favorable attitudes towards them. Hence, it endorses the view of trust being the corner stone of customer-organizaiton relationship, either the relationship is commercial or philanthropic in nature. From Islamic banks' perspective, trusting an Islamic bank goes beyond the limits of good services and safe deposits handling, which may be necessary but not suffecient for an Islamic bank to be trusted. Islamic banks to be trusted needs to comply with the Islamic law of contracts and business transactions. People may even forgo some in terms of services or quality but would not tolerate any non-Shari'ah compliance by the Islamic banks. They would not trust and opt for any Islamic bank whose operations are doubtful from Shari'ah perspective. Therefore, higher trust in terms of Shari'ah compliance and safe deposits handling of Islamic banks would of course boost favorable attitudes of the people towards them.

Surprisingly, insignificant moderating role of trust was found. It was observed that trust does not moderate the relaitonship between religiosity and attitudes towards Islamic banks, which is against our proposed hypothesis. At the same time, no existing literature is available to explain such moderating role of trust and its possible impact on the relationship between religiosity and attitudes. The unexpected result may be due to the fact that Islamic banks currently are very less in number and similar in operations to each other. Therefore, people do not have much options to switch from less trusted to a more trusted Islamic bank. Secondly, Muslims would of course prefer Islamic banks over their conventional counterparts when it comes to decide for opting between the two, because religious inclination would always instigate for some how Shariah compliant banking as compared to interest based conventional banking.

\section{Practical Implications}

It is recommended for Islamic banks and regulatory bodies supervising Islamic banks to create awareness and educate people about the distinct status of Islamic banking. It should be clarified that Islamic banks work under the principles of Shariah and do not indulge in any Islamically prohibited activity. Moreover, the difference between conventional and Islamic banking must 
also be made clear so that people with religious inclination can be banked due to their highly favorable attitudes towards Is lamic banks. Secondly, Islamic banks are advised to maintain high level of credibility and trustworthiness. Trust in terms of Shari'ah compliance and safe handling of deposits have strong influential role in building positive attitudes towards Islamic banks. Regulatory bodies in cooperation with Islamic banks may develop a robust mechanism ensuring complete Shariah compliance and safe deposit handling so that trust of the customers may not be compromised.

\section{Limitations and Directions for Future Research}

The findings and practical implications should be dealt with vigilance and carefulness due to several limitations of this study. Data was collected through convenient sampling technique sourced through a cross sectional design. Moreover, the study was based on a small sample size of II3 respondents where majority of the respondents were male. Therefore, generalizability may be considered with caution. Thus, it is recommended that future studies may adopt a probability sampling technique sourced by data lag sampling design. Furthermore, to ensure generalizability, future researchers are advised to use a larger and diverse sample size. At the same time, they may consider other independent variables like image of Islamic banks. Similarly, other behavioral variables like consumer's knowledge may be used as moderators to further explain the attitudes towards Islamic banks from different possible dimensions.

\section{References}

Abou Youssef, M. M., Kortam, W., Abou Aish, E., \& El-Bassiouny, N. (20I5). Effects of religiosity on consumer attitudes toward Islamic banking in Egypt. International Joumal of Bank Marketing , 33 (6), 786-807.

Ajzen, I., \& Fishbein, M. (1977). Attitude-behavior relations: A theoretical analysis and review of empirical research. Psychological Bulletin , 84(5), 888-918.

Amin, M., Isa, Z., \& Fontaine, R. (20I3). Islamic banks: Contrasting the drivers of customer satisfaction on image, trust, and loyalty of Muslim and non-Muslim customers in Malaysia. International Journal of Bank Marketing , 31 (2), $79-97$.

Butt, I. S. (20I I). Barriers to adoption of Islamic banking in Pakistan. Journal of Islamic Marketing , 2 (3), $259-273$.

Butt, M. M., \& Aftab, M. (2013). Incorporating attitude towards Halal banking in an integrated service quality, satisfaction, trust and loyalty model in online Islamic banking context. International Journal of Bank Marketing , 3I (I), 6-23.

Cohen, J., Cohen, P., West, S. G., \& Aiken, L. S. (2013). Applied multiple regression/correlation analysis for the behavioral sciences. Routledge.

Corritore, C. L., Kracher, B., \& Wiedenbeck, S. (2003). On-line trust: concepts, evolving themes, a model. International Journal of Human-Computer Studies , 58 (6), 737-758.

Davis, L. (2016). Religiosity and retail store choices: Exploring US christian consumers' apparel shopping behavior. International Journal of Business Anthropology , 6(I), 47.

Eagly, A., \& Chaiken, S. (1993). The psychology of attitudes. Harcout Brace Jovanovich College Publishers.

El-Menouar, Y., \& Stiftung, B. (20I4). The five dimensions of Muslim religiosity: Results of an empirical study. Methods, Data, Analyses , $8(\mathrm{I}), 53-78$.

Ennew, C., Sekhon, H. S., \& Kharouf, H. (20I I). Trust in UK financial services: A longitudinal analysis. Journal of Financial Services Marketing , I6 (I), 65-75.

Essoo, N., \& Dibb, S. (2004). Religious influences on shopping behaviour: an exploratory study. Journal of Marketing Management, $20(7 / 8), 683-712$.

Faisal, M., Akhtar, A., \& Rehman, A. (2014). Attitude of Muslims and non-Muslims towards Islamic banking - An exploratory study. The Developing Role of Islamic Banking and Finance: From Local to Global Perspectives, I4I162.

Flavian, C., Torres, E., \& Guinaliu, M. (2005). The influence of corporate image on consumer trust: A comparative analysis in traditional versus internet banking. Internet Research, I5 (4), 447-470.

Garbarino, E., \& Lee, O. F. (2003). Dynamic pricing in Internet retail: Effects on consumer trust. Psychology \& Marketing , 20 (6), 495-5I3.

Gerrard, P., \& Cunningham, B. (1997). Islamic banking: a study in Singapore. International Journal of Bank Marketing , I5 (6), 204-216.

Hirschman, E. (I983). Religious affiliation and consumption processes: an initial paradigm. Research in marketing , 6 (I), I3I-I70.

Hoq, M. Z., Sultana, N., \& Amin, M. (2010). The effect of trust, customer satisfaction and image on customers' loyalty in Islamic banking sector. South Asian Joumal of Management, I7(I), 70-93.

Jiang, P., Jones, D. B., \& Javie, S. (2008). How third-party certification programs relate to consumer trust in online transactions: An exploratory study. Psychology \& Marketing , 25 (9), 839-858. 
Johnson, D., \& Grayson, K. (2005). Cognitive and affective trust in service relationships. Journal of Business Research , 58 (4), 500-507.

Kantsperger, R., \& Kunz, W. (2010). Consumer trust in service companies: a multiple mediating analysis. Managing Service Quality: An International Joumal , 20 (I), 4-25.

Kolar, T., \& Zabkar, V. (20I4). The effect of general consumer attitudes and personality traits on attitudes towards domestic and multinational products in the Balkan region. Journal of East European Management Studies, I9(I), 58-60.

Lee, B. (2012). The determinants of consumer attitude toward service innovation - the evidence of ETC system in Taiwan. Journal of Services Marketing , $26(\mathrm{I}), 9-19$.

Lee, K., \& Ullah, S. (20II). Customers' attitude toward Islamic banking in Pakistan. International Journal of Islamic and Middle Eastern Finance and Management, 4(2), I3I-I46.

Lee, K., \& Ullah, S. (2007). Integration of Islamic and conventional finance. International Review of Business Research Papers , $3(5), 24 \mathrm{I}-65$.

Lee, K., \& Ullah, S. (2008). Inter-bank Cooperation between Islamic and conventional. International Review of Business Research Papers , 4(4), I-26.

Lewicki, R. J., \& Bunker, B. B. (1996). Developing and maintaining trust in work relationships. Trust in organizations: Frontiers of theory and research, II4-139.

Lewis, J. D., \& Weigert, A. (1985). Trust as a social reality. Social Forces , 63 (4), 967-985.

Mc Daniel, S. W., \& Burnett, J. J. (1990). Consumer religiosity and retail store evaluative criteria. Journal of the Academy of Marketing Science, I8(2), IOI-II2.

McKnight, D. H., \& Chervany, N. L. (1996). The meanings of trust.

Newaz, F. T., Fam, K., \& Sharma, R. R. (2016). Muslim religiosity and purchase Intention of different categories of Islamic financial products. Joumal of Financial Services , 2 I (2), I4I-I52.

O'Connell, B. (1975). Dimensions of religiosity among catholics. Review of Religious Research , I6 (3), I98-207.

Osman, I. A. (2009). Customers satisfaction in Malaysian Islamic banking. International Journal of Economics and Finance , I (I), 197.

Rehman, A., \& Shabbir, M. (2010). The relationship between religiosity and new product adoption. Journal Islamic Marketing , $I(\mathrm{I}), 63-69$.

Riegelsberger, J., Sasse, M. A., \& McCarthy, J. D. (2005). The mechanics of trust: A framework for research and design. International Journal of Human-Computer Studies , 62 (3), 38I-422.

Sargeant, A., \& Lee, S. (2004). Trust and relationship commitment in the United Kingdom voluntary sector: Determinants of donor behavior. Psychology \& Marketing , 21 (8), 613-635.

Sekhon, H., Roy, S., Shergill, G., \& Pritchad, A. (20I3). Modelling trust in service relationships: a transnational perspective. Journal of Services Marketing , 27(I), 76-86.

Setyobudi, W. T., Wiryono, S. K., Nasution, R. A., \& \& Purwanegara, M. S. (2015). Exploring implicit and explicit attitude toward saving at Islamic bank. Journal of Islamic Marketing , 6 (3), 3I4-330.

Sood, J., \& Nasu, Y. (I995). Religiosity and nationality: An exploratory study of their effect on consumer behavior in Japan and the United States. Joumal of Business Research, 34 (I), I-9.

Souiden, N., \& Rani, M. (2015). Consumer attitudes and purchase intentions toward Islamic banks: the influence of religiosity. International Journal of Bank Marketing , 33(4), 423-44I.

Sulaiman, M. (2003). The influence of riba and zakat on Islamic accounting. Indonesian Management and Accounting Review , 2(2), I49-167.

Swinyard, W., Kau, A., \& Phua, H. (200I). Happiness, materialism, and religious experience in the US and Singapore. Journal of Happiness Studies , 2 ( I), I3-32.

Udell, J. G. (I965). Can attitude measurement predict consumer behavior? Journal of Marketing , 29 (4), 46-50.

Williamson, O. (I993). Calculativeness, trust, and economic organization. Journal of Law and Economics , 36 (I), 453-86.

\section{Copyrights}

Copyright for this article is retained by the author(s), with first publication rights granted to the journal. This is an open-access article distributed under the terms and conditions of the Creative Commons Attribution license (http://creativecommons.org/licenses/by/4.0/). 